\title{
Emerging role of extracellular nucleotides and adenosine in multiple sclerosis
}

\author{
Marek Cieślak • Filip Kukulski • Michał Komoszyński
}

Received: 31 May 2011 / Accepted: 11 July 2011 /Published online: 27 July 2011

(C) The Author(s). This article is published with open access at Springerlink.com 2011

\begin{abstract}
Extracellular nucleotides and adenosine play important roles in inflammation. These signaling molecules interact with the cell-surface-located P2 and P1 receptors, respectively, that are widely distributed in the central nervous system and generally exert opposite effects on immune responses. Indeed, extracellular ATP, ADP, UTP, and UDP serve as alarmins or damage-associated molecular patterns that activate mainly proinflammatory mechanisms, whereas adenosine has potent anti-inflammatory and immunosuppressive effects. This review discusses the actual and potential role of extracellular nucleotides and adenosine in multiple sclerosis (MS).
\end{abstract}

Keywords Neuroinflammation · Demyelination ·

Autoimmune encephalomyelitis $\cdot \mathrm{P} 2$ receptor $\cdot \mathrm{P} 1$ receptor

\section{Introduction}

Multiple sclerosis (MS) is a debilitating autoimmune disease of the central nervous system (CNS) that leads to

\footnotetext{
M. Cieślak ( $\bowtie)$

Department of Neurology, WSZ Hospital,

53/59 St. Joseph Street,

Torun 87-100, Poland

e-mail: marcies@autograf.pl

F. Kukulski

Centre de Recherche en Rhumatologie et Immunologie,

Centre Hospitalier Universitaire de Québec,

2705 Blvd. Laurier, Local T1-49,

Québec, QC G1W1L1, Canada

M. Komoszyński

Department of Biochemistry, Nicolaus Copernicus University,

7/9 Gagarina Street,

Toruń 87-100, Poland
}

progressive physical and cognitive disability. The complex etiology of MS includes the combination of genetic, environmental, and infectious factors. Wallerian degeneration, i.e., axonal injury and death resulting from demyelination, represents the major pathological symptom of MS. Axon degeneration is followed by the atrophy of dendrites and neuronal cell bodies, which altogether result in local loss of neurological function $[1,2]$. Demyelination process observed in MS patients is heterogeneous and seems to result from either autoimmunity (i.e., the T cell-mediated or $\mathrm{T}$ cell-mediated plus antibody-mediated encephalomyelitis) or a dystrophy of the myelinating cell oligodendrocyte [3]. Prevalent evidence demonstrates that MS progression is associated with relapsing inflammation in disease lesions (called plaques) $[4,5]$. In agreement, active plaques show the presence of various immune cells such as $\mathrm{T}$ and $\mathrm{B}$ lymphocytes, glial cells (microglia, oligodendroglia, and astrocytes), dendritic cells, monocytes/macrophages, and neutrophils. All these cells contribute to neuroinjury by secreting a wide array of proinflammatory cytokines that exacerbate inflammation and promote chronic astrogliosis $[6,7]$. Interestingly, although activated $B$ lymphocytes produce antibodies against oligodendrocytes and myelin which manifests in the presence of oligoclonal bands in the cerebrospinal fluid in $95 \%$ of MS patients [8], the role of these antibodies in the etiology of MS has not been demonstrated.

Neuroinflammation is associated with high levels of extracellular ATP which is released from activated cells or leaks from injured or dead cells [9]. The cells involved in MS, i.e., neurons, glia, and immigrated immune cells, can sense this molecule, as well as other extracellular nucleotides (e.g., ADP, UTP, and UDP), via specific P2 receptors. This family of receptors includes ionotropic P2X (P2X1-7) and metabotropic P2Y (P2Y $1,2,4,6,11-14)$ receptors that differ 
in respect to specificity towards nucleotides: all $\mathrm{P} 2 \mathrm{X}$ and $\mathrm{P}_{2} \mathrm{Y}_{11}$ receptors are activated by ATP; $\mathrm{P} 2 \mathrm{Y}_{2}$ by ATP and UTP; $\mathrm{P}_{1} \mathrm{Y}_{1}, \mathrm{P}_{2} \mathrm{Y}_{12}$, and $\mathrm{P} 2 \mathrm{Y}_{13}$ by ADP; $\mathrm{P}_{2} \mathrm{Y}_{4}$ by UTP; $\mathrm{P}^{2} \mathrm{Y}_{6}$ by UDP; and $\mathrm{P} 2 \mathrm{Y}_{14}$ by UDP glucose [10]. Mounting evidence links the release of extracellular nucleotides with the induction of a myriad of proinflammatory responses such as the production of inflammatory mediators and the proliferation, differentiation, trafficking, and apoptosis of immune cells $[6,11]$. Cells involved in MS also express $\mathrm{P} 1$ receptors, namely $\mathrm{A}_{1}, \mathrm{~A}_{2 \mathrm{~A}}, \mathrm{~A}_{2 \mathrm{~B}}$, and $\mathrm{A}_{3}$, that are activated by extracellular adenosine $[12,13]$. This molecule is produced mainly from the degradation of extracellular ATP and ADP by the ectonucleotidases nucleoside triphosphate diphosphohydrolases (NTPDases) and ecto-5'-nucleotidase [14, 15]. In contrast to P2 receptors, $\mathrm{P} 1$ receptors generally exert anti-inflammatory and immunosuppressive responses.

This review discusses the actual and potential roles of extracellular nucleotides and adenosine in MS.

\section{Role of extracellular nucleotides and $\mathrm{P} 2$ receptors in MS}

The proinflammatory $\mathrm{P} 2 \mathrm{X} 7$ receptor, previously known as a death receptor or $\mathrm{P} 2 \mathrm{Z}$, is one of the most abundant $\mathrm{P} 2$ receptors in the CNS. It is expressed either by resident cells (e.g., microglia, oligodendroglia, astrocytes, and Schwann cells) or leukocytes infiltrating the CNS during immune responses (lymphocytes, monocytes, and macrophages) [7, 16-18]. The biological role of P2X7 is closely associated with inflammatory process that increases the expression of this receptor and also generates large quantities of extracellular ATP required for its activation [9, 19]. In line with the role of $\mathrm{P} 2 \mathrm{X} 7$ in MS, the expression of this receptor is significantly elevated in neurons and astrocytes of MS patients and in brain samples from rodents subjected to experimental autoimmune encephalomyelitis, which is an animal model of MS [20-22]. Moreover, increased P2X7immunoreactivities have been found in microglial cells and macrophages of MS and amyotrophic lateral sclerosis spinal cord [17]. Typically, the stimulation of P2X7 activates multiple signaling pathways, e.g., $\mathrm{Ca}^{2+}$ influx, $\mathrm{K}^{+}$efflux, mitogen-activated protein kinases, phospholipases $\mathrm{D}$, and $\mathrm{A}_{2}$, and nuclear factor kappa $\mathrm{B}$ [23-25], and these next trigger a cascade of responses including the release of proinflammatory mediators and excitatory neurotransmitters, cell proliferation, and death.

The hallmark response resulting from P2X7 stimulation is the maturation and release of the cytokine interleukin- $1 \beta$ (IL-1 $\beta$ ) via $\mathrm{K}^{+}$efflux-dependent activation of caspase 1 $[11,19,23,26]$. Several studies have demonstrated that IL$1 \beta$ released by P2X7 is secreted in the form of microvesicles. Specifically, it was shown that P2X7 activation triggers dramatic morphological changes at the plasma membrane of monocytes, microglia, dendritic cells, and astrocytes by inducing membrane protrusions that are followed by shedding of microvesicles loaded with IL- $1 \beta$ [27-30]. Once released, IL-1 $\beta$ triggers the activation of cyclooxygenase-2 (COX-2) and inducible nitric oxide synthase (iNOS), as well as, the production of proinflammatory cytokines IL-2 (IL-1 $\beta$ also upregulates the expression of the receptor for this cytokine), tumor necrosis factor alpha (TNF- $\alpha)$, interferon- $\gamma$ (IFN- $\gamma)$, and IL-6 $[16,23]$. These responses considerably contribute to MS. Indeed, the products of COX-2 and iNOS increase the concentration of glutamate to a high cytotoxic level which accelerates neuronal injury. Specifically, the prostanoids produced by COX-2 increase glutamate release whereas the reactive oxygen species produced as the side-products of prostanoid synthesis and nitric oxide generated by iNOS inhibit the uptake of this excitatory neurotransmitter [31-33]. In addition to glutamate, P2X7 stimulation increases the release of glycine that is also an excitatory neurotransmitter $[16,23,34]$.

The cytokines induced by IL-1 $\beta$ also play a key role in MS. For example, IL-2 stimulates the proliferation, differentiation and survival of antigen-selected cytotoxic T cells. Moreover, this cytokine is also necessary for the maturation of regulatory $\mathrm{T}$ cells (Tregs) that prevent other $\mathrm{T}$ cells from recognizing and reacting against "self antigens" [35]. TNF$\alpha$ is involved in the control of synaptic strength and mediates the alteration of excitatory transmission occurring in MS [36]. Together with IFN- $\gamma$ and IL-6, this cytokine also controls immune cell recruitment by increasing the expression of adhesion molecules, namely intercellular adhesion molecule-1, vascular cell adhesion molecule-1 (VCAM-1), and E-selectin, at the surface of endothelium. Notably, natalizumab (Tysabri, Elan Pharma International Ltd.), a monoclonal antibody directed against $\alpha 4$ integrin (binds endothelial VCAM-1) expressed at the lymphocyte surface is currently used in MS therapy. In addition, P2X7 is also implicated in $N$-formyl-Met-Leu-Phe (also known as fMLF or fMLP)-induced expression of CD11b (or $\alpha_{M} \beta_{2}$, a subunit of MAC-1) in human neutrophils which regulates the transendothelial migration of these cells $[37,38]$.

P2X7 plays an important role in glial cells where, depending on the conditions, its activation can stimulate either proliferation or apoptosis. The former response was observed in the monoculture of microglial cells treated with exogenous ATP at milimolar concentration $[39,40]$ whereas the latter response was exerted by repetitive receptor activation by endogenous ATP released from astrocytes co-cultured with microglia [41]. Interestingly, IFN- $\gamma$ that greatly potentiates ATP release from astrocytes further increased microglial apoptosis. In addition, it was demonstrated that the activation of $\mathrm{P} 2 \mathrm{X} 7$ receptors can kill 
oligodendocytes in vitro [20]. This P2X7-induced response appears to have an important role in chronic autoimmune encephalomyelitis, where a sustained activation of P2X7 receptors leads to lesions resembling MS plaques in respect to demyelination, oligodendrocyte death, and axonal damage. In agreement with the role of P2X7 in this model, severity of encephalomyelitis was significantly reduced either in P2X7 knockout mice or in wild-type mice treated with P2X7 antagonists [20, 42]. In contrast, another study demonstrated an exacerbated experimental autoimmune encephalomyelitis in P2X7 knockout mice which was attributed to a loss of apoptotic activity in lymphocytes [43]. These stark differences in the outcome of encephalomyelitis between studies using P2X7 knockout mice may result from differences in phenotype of mice used. Indeed, these studies were done with P2X7 knockout mice generated by GlaxoSmithKline and Pfizer, respectively, which, to our knowledge, tend to give conflicting results. In addition to proliferation and apoptosis, $\mathrm{P} 2 \mathrm{X} 7$ stimulation in microglia can also activate superoxide production and ATP release [40, 44]. The latter response subsequently increases microglia activation by triggering intracellular $\mathrm{Ca}^{2+}$ waves in an autocrine manner. Due to well-documented and important role of $\mathrm{P} 2 \mathrm{X} 7$ in neuroinflammation, the antagonists of this receptor are currently tested as potential treatments against inflammatory diseases of the CNS [45-47].

Another ATP-activated P2 receptor involved in inflammation, that could therefore play a role in MS, is $\mathrm{P} 2 \mathrm{Y}_{11}$. This receptor is expressed by granulocytes, dendritic cells and lymphocytes [48-50]. In neutrophils, the activation of $\mathrm{P} 2 \mathrm{Y}_{11}$ protects against apoptosis and triggers chemotaxis $[51,52]$. In dendritic cells, $\mathrm{P} 2 \mathrm{Y}_{11}$ controls the production of cytokines responsible for the key innate and adaptative immune responses, i.e., it induces the release of IL-10 and IL-23 but inhibits the release of IL-12 and IL-27. IL-10 is a potent anti-inflammatory cytokine that inhibits the synthesis of multiple proinflammatory cytokines (IFN- $\gamma$, IL-2, IL-3, TNF- $\alpha$, and GM-CSF) and attenuates the antigen presentation capacity of antigen presenting cells. IL-23 stimulates the proliferation and increases cytotoxicity of $\mathrm{T}$ lymphocytes, and also induces the release of IL-17 by T-helper cells that subsequently triggers leukocyte recruitment. In addition, IL23 is necessary for the generation of T-memory cells and autoimmunity, and thus plays a role in autoimmune diseases such as autoimmune encephalomyelitis. IL-12 and IL-27 promote Th1 response by stimulating the production of IFN- $\gamma$ in natural killers (NK) cells and natural killer T (NKT) cells [49]. IL-12 also enhances the proliferation, activation and cytotoxicity of NK and cytotoxic $\mathrm{T}$ cells but inhibits their IFN- $\gamma$ and TNF- $\alpha$ secretion.

The $\mathrm{P}_{2} \mathrm{Y}_{2}$ receptor activated by ATP and UTP is expressed by neurons, astrocytes, microglia and leukocytes [53]. The expression of this receptor can be upregulated by proinflammatory cytokines such as IL-1 $\beta$ [54]. Interestingly, it is likely that $\mathrm{P}_{2} \mathrm{Y}_{2}$ may increase its own expression via a positive loop mechanism involving $\mathrm{P}_{2} \mathrm{Y}_{2}$-dependent and metaloprotease-induced activation of IL- $1 \beta$ production in astrocytes and primary neurons. The major role of $\mathrm{P}_{2} \mathrm{Y}_{2}$ in inflammation seems to be associated with cell migration. Indeed, this receptor controls the migration of glial cells [53] and leukocytes [55-58]. The migration of the latter cells involves either endothelial $\mathrm{P}_{2} \mathrm{Y}_{2}$ receptors whose stimulation upregulates the expression of adhesion molecules such as VCAM-1 or leukocyte $\mathrm{P}_{2} \mathrm{Y}_{2}$ receptors that trigger the release of chemokines IL-8 and MCP-1 [55, 58-60].

In agreement with an important role of ATP-activated receptors in neuroinflammation and MS, a nonsynaptic release of this nucleotide has been reported in the CNS that allows communication between axons and myelinating glia and has been shown to regulate myelination process [61]. Thus, it seems likely that the disregulation of nonsynaptic ATP release and thus alterations in P2 receptor-dependent neuron-to-glia crosstalk may disregulate myelination, and, conversely, its normalization might be beneficial in MS.

The ADP-activated $\mathrm{P}_{2} \mathrm{Y}_{12}$ is expressed by oligodendrocytes, microglia and astrocytes [62, 63], and appears to play an important role in myelination process. Indeed, there is an inverse correlation between the decrease in $\mathrm{P}_{2} \mathrm{Y}_{12}$ expression and both axonal damage and gray matter demyelination occurring in frontal cortex during the secondary progressive phase of MS [64]. In microglia, $\mathrm{P}_{2} \mathrm{Y}_{12}$ receptor plays an important role in chemotaxis [63], and as microglia present in MS lesions are negative for $\mathrm{P}_{2} \mathrm{Y}_{12}$ immunostaining [64], it is likely that at least some of the effects described above might be due to impeded microglia function that would hamper debris clearance and thus either exacerbate neurodegeneration or hamper regeneration [65]. This is in agreement with the role of glial cells in both destructive and restorative phases of MS.

The UDP-sensitive $\mathrm{P}_{2} \mathrm{Y}_{6}$ receptor is widely expressed in brain blood vessels (in vascular smooth muscle cells and endothelium) and by immune cells such as microglia and monocytes/macrophages [10]. The major role of this receptor in inflammation is associated with the production of the chemokine IL-8 that has a key role in inflammatory leukocyte recruitment $[58,60,66] . \mathrm{P}^{2} \mathrm{Y}_{6}$ is also involved in microglia phagocytosis [67].

The GPR17 receptor activated by both uracil nucleotides and cysteinyl leukotrienes (e.g., UDP glucose and LTD4) is expressed in neurons and a subset of parenchymal quiescent oligodendrocyte precursor cells. This receptor appears to act as a "sensor" that is activated upon brain injury and participate either in neurodegeneration or remodeling/repair response. It was shown that following brain injury, stimulation of GPR17 increases an infract size most likely by sensitizing CNS cells to ATP-induced death $[68,69]$. At 
later stages, however, GPR17 expressed in parenchymal oligodendrocyte progenitors induces differentiation of these cells into mature oligodendrocytes and, thus, promotes remyelinating process [70-72].

The role of $\mathrm{P} 2$ receptors in neuroinflammation is summarized in Table 1.

\section{Role of extracellular adenosine and $\mathrm{P1}$ receptors in MS}

Extracellular adenosine generally exerts potent antiinflammatory/immunosuppressive responses and therefore plays an essential role in neuroprotection [73]. The neuroprotective effects of this molecule in the CNS include: preconditioning, increase in the level of oxygen supply/ demand ratio, control of cytokine production, and immunosuppression. Importantly, adenosine also promotes neurorepair by stimulating cell proliferation and angiogenesis $[74,75]$. Sitkovsky and Ohta have proposed that inflammation is always associated with mild hypoxia and that the latter increases the production of extracellular adenosine as the "stop" signal for inflammation (Fig. 1; [76]). This is accomplished by: (1) increase in the metabolism of extracellular ATP, (2) increase in the production of

Table 1 Role of P2 and P1 receptors in neuroinflammation and experimental encephalomyelitis

\begin{tabular}{|c|c|c|c|c|}
\hline Receptor & Natural agonist(s) & Expression in the CNS & $\begin{array}{l}\text { Demonstrated and/or potential role } \\
\text { in the CNS }\end{array}$ & $\begin{array}{l}\text { Role in experimental } \\
\text { encephalomyelitis (EAE) }\end{array}$ \\
\hline $\mathrm{P} 2 \mathrm{X} 7$ & $\operatorname{ATP}(\mathrm{mM})$ & $\begin{array}{l}\text { Microglia astrocytes } \\
\text { oligodendroglia Schwann } \\
\text { cells leukocytes and } \\
\text { 个immunoreactivity in } \\
\text { neurons and astrocytes } \\
\text { of MS patients }\end{array}$ & $\begin{array}{l}\text { Induces IL-1 } \beta \text { maturation and } \\
\text { release } \\
\text { Regulates microglia proliferation } \\
\text { and apoptosis } \\
\text { Triggers superoxide generation and } \\
\text { ATP release by microglia }\end{array}$ & $\begin{array}{l}\mathrm{P} 2 \mathrm{X} 7 \text { stimulation causes lesions } \\
\text { resembling MS plaques } \\
\text { Significantly reduced severity } \\
\text { of EAE either in } \mathrm{P} 2 \mathrm{X} 7 \\
\text { knockout mice or in wild-type } \\
\text { mice treated with } \mathrm{P} 2 \mathrm{X} 7 \\
\text { antagonists }\end{array}$ \\
\hline $\mathrm{P} 2 \mathrm{Y}_{2}$ & ATP and UTP & $\begin{array}{l}\text { Neurons, microglia, } \\
\text { astrocytes, and leukocytes }\end{array}$ & $\begin{array}{l}\text { Controls migration of glial cells } \\
\text { and leukocytes } \\
\text { Triggers the release of chemokines } \\
\text { IL- } 8 \text { and MCP-1 }\end{array}$ & ND \\
\hline $\mathrm{P} 2 \mathrm{Y}_{6}$ & UDP & $\begin{array}{l}\text { Microglia, leukocytes, and } \\
\text { blood vessel cells }\end{array}$ & $\begin{array}{l}\text { Controls leukocyte recruitment via } \\
\text { IL- } 8 \text { production } \\
\text { Controls microglia phagocytosis }\end{array}$ & ND \\
\hline $\mathrm{P} 2 \mathrm{Y}_{11}$ & ATP and ADP & Leukocytes & $\begin{array}{l}\text { Involved in neutrophil chemotaxis } \\
\text { and apoptosis } \\
\text { Controls key immune responses of } \\
\text { dendritic cells }\end{array}$ & ND \\
\hline $\mathrm{P} 2 \mathrm{Y}_{12}$ & ADP & $\begin{array}{l}\text { Oligodendrocytes, microglia, } \\
\text { and astrocytes }\end{array}$ & Involved in myelination & ND \\
\hline GPR17 & $\begin{array}{l}\text { UDP, UDP } \\
\text { glucose, and } \\
\text { cysteinyl } \\
\text { leukotrienes }\end{array}$ & $\begin{array}{l}\text { Neurons, parenchymal, } \\
\text { oligodendrocyte, and } \\
\text { precursor cells }\end{array}$ & $\begin{array}{l}\text { Involved in neurodegeneration and } \\
\text { remodeling/repair processes } \\
\text { following brain injury }\end{array}$ & ND \\
\hline $\mathrm{A}_{1}$ & Adenosine & $\begin{array}{l}\text { Neurons, microglia, astrocytes, } \\
\text { leukocytes (except for T } \\
\text { lymphocytes), and } \downarrow \text { expression } \\
\text { in MS patients }\end{array}$ & $\begin{array}{l}\text { Protects against neuroinflammation } \\
\text { and demyelination in patients } \\
\text { with MS and allergic EAE } \\
\text { Promotes tissue repair via } \\
\text { stimulation of neuronal growth } \\
\text { factor release from astrocytes }\end{array}$ & $\begin{array}{l}\text { A1 knockout mice display } \\
\text { increased neuroinflammation } \\
\text { and demyelination }\end{array}$ \\
\hline $\mathrm{A}_{2 \mathrm{~A}}$ and $\mathrm{A}_{2 \mathrm{~B}}$ & Adenosine & $\begin{array}{l}\text { Neurons, microglia (except } \\
\left.\text { for } A_{2 B}\right) \text {, astrocytes, and } \\
\text { leukocyte }\end{array}$ & $\begin{array}{l}\mathrm{A}_{2 \mathrm{~A}} \text { knockout mice display an } \\
\text { increased production of } \\
\text { proinflammatory cytokines } \\
\text { Antagonize } \mathrm{T} \text { cell receptor } \\
\text { signalling and IL-2 release }\end{array}$ & ND \\
\hline A3 & Adenosine & $\begin{array}{l}\text { Neurons, microglia, astrocytes, } \\
\text { and leukocytes }\end{array}$ & $\begin{array}{l}\text { Induces the release of IL- } 6 \text { and } \\
\text { CCL2 from astrocytes } \\
\text { Decreases LPS-induced TNF- } \alpha \\
\text { production by microglia and NK } \\
\text { activation }\end{array}$ & ND \\
\hline
\end{tabular}

$N D$ not determined 
Fig. 1 The role of adenosine and $\mathrm{P} 1$ receptors in inflammation

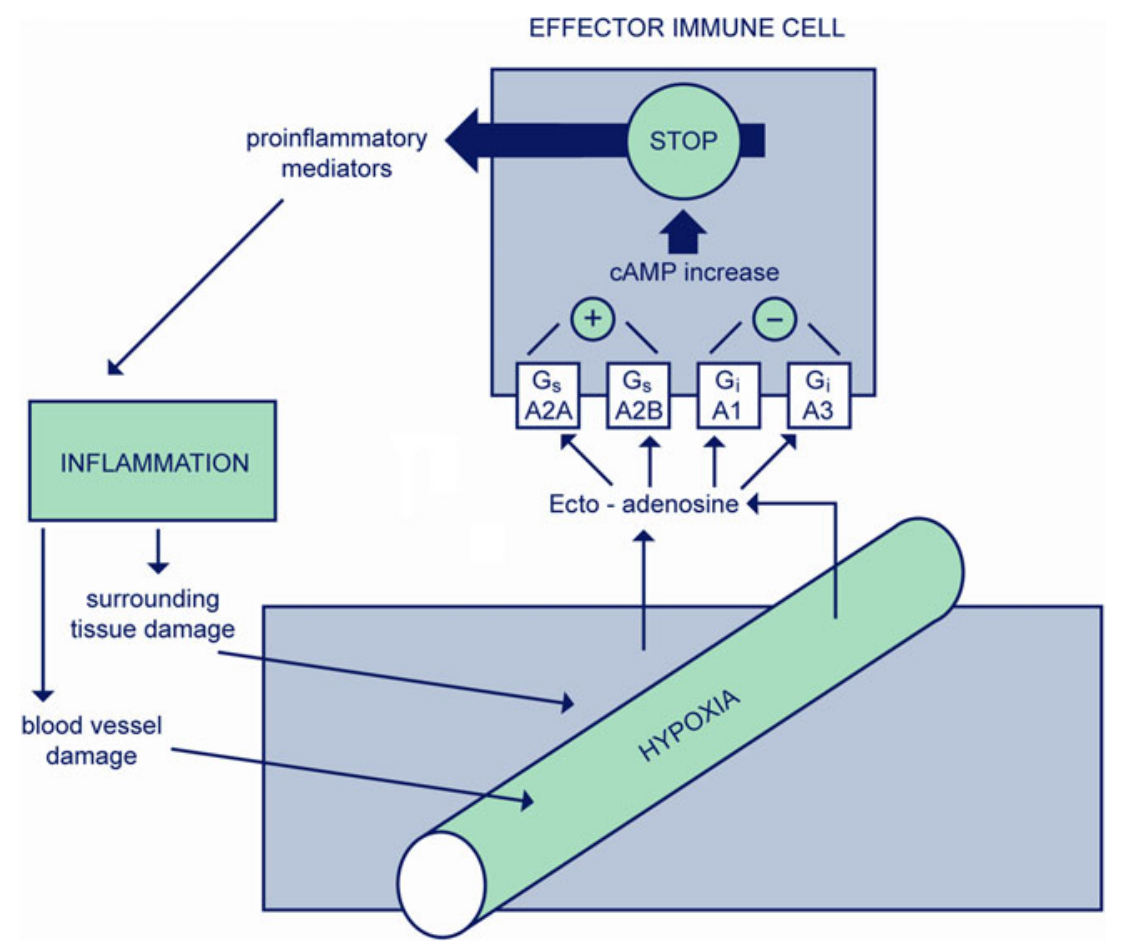

intracellular adenosine and its transport outside the cells, and (3) decrease in adenosine kinase activity that phosphorylates adenosine to AMP in physiological conditions [77]. The (1) is possible due to, for example, increase in the expression of the ectonucleotidases NTPDase1 and ecto-5'nucleotidase via induction of transcription factors $\mathrm{Sp} 1$ and hypoxia-inducible factor-1 (HIF-1), respectively (see "Role of ectoenzymes metabolizing extracellular nucleotides and adenosine in MS"; [78, 79]). All these mechanisms can rapidly raise the concentration of extracellular adenosine from basal nanomolar to $\sim 10-50 \mu \mathrm{M}$ [80]. Adenosine acts through the activation of four types of $\mathrm{P} 1$ receptors, namely $A_{1}, A_{2 A}, A_{2 B}$, and $A_{3} . A_{1}$ and $A_{2 A}$ receptors require lower concentrations of adenosine for activation than $A_{2 B}$ and $A_{3}$. All P1 receptor subtypes are expressed by neurons and glial cells except for microglia that do not express $A_{2 B}[75,80]$.

Among P1 receptors, the $A_{1}$ receptor appears to have the most profound neuroprotective role in the CNS. For example, together with $\mathrm{A}_{3}$, this receptor is implicated in brain ischemic preconditioning [75]. Moreover, $A_{1}$ stimulation protects against neuroinflammation and demyelination in patients with MS and allergic encephalitis [81]. In agreement, $A_{1}$ receptor knockout mice develop severe demyelination and oligodendrocyte cytotoxicity due to increased production of IL-1 $\beta$ and metalloproteinase-12 by macrophages. This finding is in line with the decreased expression of $A_{1}$ receptors in peripheral blood mononuclear cells, microglia and macrophages from MS patients [82, 83]. The neuronal $A_{1}$ receptors also contribute to neuroprotection by inhibiting the release of excitatory neuro- transmitters and attenuating the propagation of their signaling [84]. In addition to neuroprotection, $A_{1}$ receptors are involved in tissue repair via stimulation of neuronal growth factor release from astrocytes [85].

The activation of $\mathrm{A}_{2 \mathrm{~A}}$ and $\mathrm{A}_{2 \mathrm{~B}}$ receptors leads to increase in intracellular cAMP that has a general inhibitory effect on immune cells (Fig. 2). While prevalent evidence indicates that the activation of $\mathrm{A}_{2 \mathrm{~A}}$ initiates potent anti-

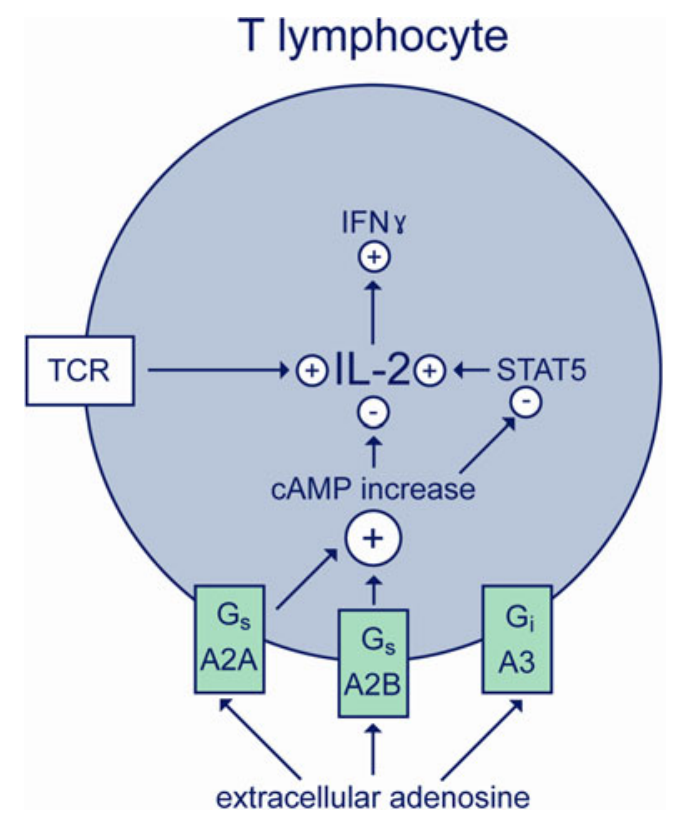

Fig. 2 The role of $\mathrm{P} 1$ receptors in the regulation of $\mathrm{T}$ lymphocyte functions 
inflammatory responses, the role of this receptor in the CNS remains controversial as its activation is detrimental in cerebral ischemia but beneficial in lipopolysaccharide (LPS)-induced meningitis [80]. The results obtained from the model of liver injury show that $\mathrm{A}_{2 \mathrm{~A}}$ deletion in mice exacerbates inflammation through increased production of TNF- $\alpha$, IL-12, and IFN- $\gamma$. Similar effects were observed in animals treated with the $\mathrm{A}_{2 \mathrm{~A}}$ antagonist ZM241385 that markedly increased severity of liver damage compared with untreated mice [76]. The protective role of $\mathrm{A}_{2 \mathrm{~A}}$ receptor in liver injury was most probably due to dendritic cells as the stimulation of $\mathrm{A}_{2 \mathrm{~A}}$ in these cells inhibits the release of proinflammatory TNF- $\alpha$, IL-12, and chemokine CXCL10 but increases the release of anti-inflammatory IL-10 and CCL17 [75]. In glial cells, the activation of $\mathrm{A}_{2 \mathrm{~A}}$ decreases the induction of iNOS by LPS, IFN- $\gamma$, TNF- $\alpha$ and IL- $1 \beta$ but increases COX-2 expression [75]. $\mathrm{A}_{2 \mathrm{~A}}$ stimulation also exerts potent immunosuppressive effects on $\mathrm{T}$ lymphocytes by antagonizing $\mathrm{T}$ cell receptor (TCR) signaling that activates the release of cytokines (e.g. IL-2) and granules, upregulates the expression of CD25, CD69 and Fas ligand, and increases the cytotoxicity and proliferation of $\mathrm{T}$ cells [86].

As mentioned above, $A_{2 B}$ receptor requires higher concentration of adenosine for activation then $\mathrm{A}_{2 \mathrm{~A}}$ suggesting that the former receptor may be more important in pathological conditions where it would potentiate the responses triggered by $\mathrm{A}_{2 \mathrm{~A}}$ activation. In agreement, the functional responses of $\mathrm{A}_{2 \mathrm{~B}}$ in astrocytes were increased by prior stimulation with TNF- $\alpha$ [87]. The activation of $A_{2 B}$ receptors in $T$ cells results in the inhibition of IL-2 production [86] whereas in astrocytes, $A_{2 B}$, together with $\mathrm{A}_{3}$ receptors, induce the release of IL-6 and CCL2 [88, 89]. The activation of $A_{3}$ receptor was also shown to decrease LPS-induced TNF- $\alpha$ production by microglia and NK activation $[86,90]$.

Interestingly, in some cells, adenosine can exert opposite biological effects depending on the activated $\mathrm{P} 1$ receptors. For example, $\mathrm{A}_{1}$ stimulates astrocyte proliferation whereas $\mathrm{A}_{2 \mathrm{~A}}$ inhibits this process [80]. Therefore, given that either neurons or glial cells express all four P1 receptor subtypes, the final effect of extracellular adenosine will depend on P1 subtype expression level, adenosine concentration and environmental conditions (e.g., cytokine production). The role of P1 receptors in neuroinflammation is summarized in Table 1.

\section{Role of ectoenzymes metabolizing extracellular nucleotides and adenosine in MS}

The activation of $\mathrm{P} 2$ and $\mathrm{P} 1$ receptors is regulated by ectoenzymes that metabolize the ligands of these receptors $[14,15]$. For example, the sequential hydrolysis of extracellular ATP to adenosine by the enzymes ectonucleo- tidases either terminates $\mathrm{P} 2$ receptor activation or promotes P1 activation. While ATP and ADP (as well as UTP and UDP) are hydrolyzed by NTPDases, AMP is dephosphorylated to adenosine by ecto-5'-nucleotidase (CD73). Some cells also possess the enzymes ectokinases, e.g., adenosine kinase, that have the capacity to re-synthesize nucleotides from their degradation products, e.g. adenosine, and thus inactivate $\mathrm{P} 1$ activation but promote $\mathrm{P} 2$ activation [15].

NTPDase1 (CD39) is a dominant ectonucleotidase originally identified as the activation marker of $\mathrm{B}$ lymphocytes [14]. In the CNS, this enzyme is expressed in synaptic membranes [91] and by microglia [7]. Moreover, also infiltrating leukocytes express CD39, e.g., Foxp $3^{+}$Treg cells (CD39 is used as a specific marker of this $\mathrm{T}$ cell subset; [92]), activated T cells, NK cells (where its expression increases upon activation), monocytes/macrophages and neutrophils [12, 93]. By contributing to the production of extracellular adenosine, NTPDase1 downregulates antigen recognition and cytotoxic $\mathrm{T}$ cell activation and thus has an important immunosuppressive role [94]. In agreement, patients with remitting/relapsing MS have significantly reduced numbers of CD39 $9^{+}$Tregs [92]. Moreover, CD39 ${ }^{+}$ Tregs from MS patients display reduced capacity to suppress IL-17 production by Th17 cells [95]. Other studies demonstrate a key role of this enzyme in cytokine production. For example, endogenous NTPDase1 tightly regulates $\mathrm{P}_{2} \mathrm{Y}_{2}-$ dependent IL-8 release by human neutrophils [96]. Endogenous NTPDase 1 also controls the release of IL-1 $\beta$ by mouse macrophages and protects these cells from ATPinduced death [97]. Exogenous NTPDase1, i.e., apyrase, was demonstrated to abolish IL-8 release by human primary monocytes and IL- $1 \alpha$ by human endothelial cells $[60,66$, 98]. The studies performed with apyrase to augment the endogenous NTPDase1 activity may reflect an in vivo situation where hypoxia associated with ongoing inflammation upregulates the expression of this enzyme via induction of transcription factor Sp1 [79]. In RAW macrophages, in turn, the increase in NTPDase1 expression can be induced by agents driving cAMP response via cAMP response elementbinding [99]. In keeping with these results, patients with relapsing-remitting MS have an increased activity of CD39 in lymphocytes [100,101]. This increase may represent a protective mechanism that will decrease the activation of proinflammatory $\mathrm{P} 2$ receptors and at the same time facilitate the activation of anti-inflammatory P1 receptors.

The expression of ecto-5'-nucleotidase in the CNS was detected in astrocytes, oligodendrocytes and microglia. Moreover, this enzyme is also present in endothelium and leukocytes [7]. As for NTPDase1, the expression of ecto5 -nucleotidase can be rapidly augmented by hypoxia via HIF-1 [78]. Interestingly, MS patients treated with IFN- $\beta$ $1 \mathrm{a}$ and IFN- $\beta-1 \mathrm{~b}$ exhibited elevated expression of ecto-5'nucleotidase in serum, astrocytes and blood-brain barrier 
endothelium that suggests that these therapies target the increase in extracellular adenosine [102, 103].

Another ectoenzyme involved in MS is adenosine deaminase (ADA). This enzyme terminates $\mathrm{P} 1$ receptor activation by degrading adenosine to inosine and its activity was detected in thymus, lymphoid tissue and $\mathrm{T}$ lymphocytes [15, 104]. In agreement with the expression pattern, adenosine deaminase controls the growth, proliferation, differentiation and transendothelial migration of lymphocytes. In keeping with the role of this enzyme in MS, lymphocytes from patients with relapsing-remitting and secondary progressive MS exhibit a markedly reduced adenosine deaminase activity. The dampened expression of ADA in MS lymphocytes may facilitate the infiltration of these cells in the CNS [86, 100, 105].

\section{Summary}

As reviewed above, mounting evidence allows to link the actions of extracellular nucleotides and adenosine with the etiology of MS. The multifaceted role of these molecules in immune responses including the release of cytokines and excitatory neurotransmitters, cell trafficking, cell proliferation and death, myelination, immunosupression, etc., opens a variety of new avenues for treatments against this debilitating disease. Moreover, we are currently testing the hypothesis whether extracellular nucleotides or adenosine measured in cerebrospinal fluid could serve as the early biomarkers of MS or the markers of the transition from remitting-relapsing $\mathrm{MS}$ to treatment-resistant secondary progressive MS ([106] and work in progress).

Open Access This article is distributed under the terms of the Creative Commons Attribution Noncommercial License which permits any noncommercial use, distribution, and reproduction in any medium, provided the original author(s) and source are credited.

\section{References}

1. Martino G, Adorini L, Rieckmann P, Hillert J, Kallmann B, Comi G, Filippi M (2002) Inflammation in multiple sclerosis: the good, the bad, and the complex. Lancet Neurol 1(8):499-509

2. Siffrin V, Vogt J, Radbruch H, Nitsch R, Zipp F (2010) Multiple sclerosis - candidate mechanisms underlying CNS atrophy. Trends Neurosci 33(4):202-210. doi:10.1016/j.tins.2010.01.002

3. Lucchinetti C, Bruck W, Parisi J, Scheithauer B, Rodriguez M, Lassmann H (2000) Heterogeneity of multiple sclerosis lesions: implications for the pathogenesis of demyelination. Ann Neurol 47(6):707-717

4. Trapp BD, Nave KA (2008) Multiple sclerosis: an immune or neurodegenerative disorder? Annu Rev Neurosci 31:247-269. doi:10.1146/annurev.neuro.30.051606.094313
5. Frischer JM, Bramow S, Dal-Bianco A, Lucchinetti CF, Rauschka H, Schmidbauer M, Laursen H, Sorensen PS, Lassmann H (2009) The relation between inflammation and neurodegeneration in multiple sclerosis brains. Brain 132(Pt 5):1175-1189. doi:10.1093/brain/awp070

6. Di Virgilio F (2007) Purinergic signalling in the immune system. A brief update. Purinergic Signal 3(1-2):1-3. doi:10.1007/ s11302-006-9048-5

7. Sperlagh B, Illes P (2007) Purinergic modulation of microglial cell activation. Purinergic Signal 3(1-2):117-127. doi:10.1007/ s11302-006-9043-x

8. Link H, Huang YM (2006) Oligoclonal bands in multiple sclerosis cerebrospinal fluid: an update on methodology and clinical usefulness. J Neuroimmunol 180(1-2):17-28. doi:10.1016/j.jneuroim.2006.07.006

9. Di Virgilio F, Ceruti S, Bramanti P, Abbracchio MP (2009) Purinergic signalling in inflammation of the central nervous system. Trends Neurosci 32(2):79-87. doi:10.1016/j. tins.2008.11.003

10. Abbracchio MP, Burnstock G, Boeynaems JM, Barnard EA, Boyer JL, Kennedy C, Knight GE, Fumagalli M, Gachet C, Jacobson KA, Weisman GA (2006) International Union of Pharmacology LVIII: update on the P2Y G protein-coupled nucleotide receptors: from molecular mechanisms and pathophysiology to therapy. Pharmacol Rev 58(3):281-341. doi:10.1124/pr.58.3.3

11. Gabel CA (2007) P2 purinergic receptor modulation of cytokine production. Purinergic Signal 3(1-2):27-38. doi:10.1007/s11302006-9034-y

12. Bours MJ, Swennen EL, Di Virgilio F, Cronstein BN, Dagnelie PC (2006) Adenosine 5'-triphosphate and adenosine as endogenous signaling molecules in immunity and inflammation. Pharmacol Ther 112(2):358-404. doi:10.1016/j.pharmthera. 2005.04.013

13. Jacobson KA, Gao ZG (2006) Adenosine receptors as therapeutic targets. Nat Rev Drug Discov 5(3):247-264. doi:10.1038/ nrd1983

14. Robson SC, Sévigny J, Zimmermann H (2006) The E-NTPDase family of ectonucleotidases: structure function relationships and pathophysiological significance. Purinergic Signal 2(2):409-430. doi:10.1007/s11302-006-9003-5

15. Kukulski FLS, Sévigny J (2011) Impact of ectoenzymes on P2 and P1 signaling. Adv Pharmacol 61:263-299

16. Narcisse L, Scemes E, Zhao Y, Lee SC, Brosnan CF (2005) The cytokine IL-1beta transiently enhances $\mathrm{P} 2 \mathrm{X} 7$ receptor expression and function in human astrocytes. Glia 49(2):245-258. doi:10.1002/glia.20110

17. Yiangou Y, Facer P, Durrenberger P, Chessell IP, Naylor A, Bountra C, Banati RR, Anand P (2006) COX-2, CB2 and P2X7immunoreactivities are increased in activated microglial cells/ macrophages of multiple sclerosis and amyotrophic lateral sclerosis spinal cord. BMC Neurol 6:12. doi:10.1186/14712377-6-12

18. Cotrina ML, Nedergaard M (2009) Physiological and pathological functions of $\mathrm{P} 2 \mathrm{X} 7$ receptor in the spinal cord. Purinergic Signal 5(2):223-232. doi:10.1007/s11302-009-9138-2

19. Lister MF, Sharkey J, Sawatzky DA, Hodgkiss JP, Davidson DJ, Rossi AG, Finlayson K (2007) The role of the purinergic P2X7 receptor in inflammation. J Inflamm (Lond) 4:5. doi:10.1186/ 1476-9255-4-5

20. Matute C, Torre I, Perez-Cerda F, Perez-Samartin A, Alberdi E, Etxebarria E, Arranz AM, Ravid R, Rodriguez-Antiguedad A, Sanchez-Gomez M, Domercq M (2007) P2X7 receptor blockade prevents ATP excitotoxicity in oligodendrocytes and ameliorates experimental autoimmune encephalomyelitis. J Neurosci 27 (35):9525-9533. doi:10.1523/JNEUROSCI.0579-07.2007 
21. Grygorowicz T, Struzynska L, Sulkowski G, Chalimoniuk M, Sulejczak D (2010) Temporal expression of P2X7 purinergic receptor during the course of experimental autoimmune encephalomyelitis. Neurochem Int 57(7):823-829. doi:10.1016/j.neuint. 2010.08.021

22. Grygorowicz T, Sulejczak D, Struzynska L (2011) Expression of purinergic $\mathrm{P} 2 \mathrm{X} 7$ receptor in rat brain during the symptomatic phase of experimental autoimmune encephalomyelitis and after recovery of neurological deficits. Acta Neurobiol Exp (Wars) 71 (1):65-73

23. Carroll WA, Donnelly-Roberts D, Jarvis MF (2009) Selective $\mathrm{P} 2 \mathrm{X} 7$ receptor antagonists for chronic inflammation and pain. Purinergic Signal 5(1):63-73. doi:10.1007/s11302-008-9110-6

24. Skaper SD, Debetto P, Giusti P (2010) The P2X7 purinergic receptor: from physiology to neurological disorders. FASEB J 24 (2):337-345. doi:10.1096/fj.09-138883

25. Erb L, Liao Z, Seye CI, Weisman GA (2006) P2 receptors: intracellular signaling. Pflugers Arch 452(5):552-562. doi:10.1007/s00424-006-0069-2

26. Hughes JP, Hatcher JP, Chessell IP (2007) The role of P2X7 in pain and inflammation. Purinergic Signal 3(1-2):163-169. doi:10.1007/s11302-006-9031-1

27. MacKenzie A, Wilson HL, Kiss-Toth E, Dower SK, North RA, Surprenant A (2001) Rapid secretion of interleukin-1beta by microvesicle shedding. Immunity 15(5):825-835

28. Bianco F, Pravettoni E, Colombo A, Schenk U, Moller T, Matteoli M, Verderio C (2005) Astrocyte-derived ATP induces vesicle shedding and IL-1 beta release from microglia. J Immunol 174(11):7268-7277

29. Pizzirani C, Ferrari D, Chiozzi P, Adinolfi E, Sandona D, Savaglio E, Di Virgilio F (2007) Stimulation of P2 receptors causes release of IL-1beta-loaded microvesicles from human dendritic cells. Blood 109(9):3856-3864. doi:10.1182/blood-2005-06-031377

30. Bianco F, Perrotta C, Novellino L, Francolini M, Riganti L, Menna E, Saglietti L, Schuchman EH, Furlan R, Clementi E, Matteoli M, Verderio C (2009) Acid sphingomyelinase activity triggers microparticle release from glial cells. EMBO J 28 (8):1043-1054. doi:10.1038/emboj.2009.45

31. Domercq M, Brambilla L, Pilati E, Marchaland J, Volterra A, Bezzi $\mathrm{P}$ (2006) $\mathrm{P}_{2} \mathrm{Y}_{1}$ receptor-evoked glutamate exocytosis from astrocytes: control by tumor necrosis factor-alpha and prostaglandins. J Biol Chem 281(41):30684-30696. doi:10.1074/jbc. M606429200

32. Trotti D, Rossi D, Gjesdal O, Levy LM, Racagni G, Danbolt NC, Volterra A (1996) Peroxynitrite inhibits glutamate transporter subtypes. J Biol Chem 271(11):5976-5979

33. Mazzola S, Lira MG, Benedetti MD, Salviati A, Ottaviani S, Malerba G, Ortombina M, Pignatti PF (2007) COX-2 promoter region polymorphisms in multiple sclerosis: lack of association of $-765 \mathrm{G}>\mathrm{C}$ with disease risk. Int J Immunogenet 34(2):71-74. doi:10.1111/j.1744-313X.2007.00675.x

34. Duan S, Anderson CM, Keung EC, Chen Y, Swanson RA (2003) P2X7 receptor-mediated release of excitatory amino acids from astrocytes. J Neurosci 23(4):1320-1328

35. Waldmann TA (2006) The biology of interleukin-2 and interleukin-15: implications for cancer therapy and vaccine design. Nat Rev Immunol 6(8):595-601. doi:10.1038/nri1901

36. Centonze D, Muzio L, Rossi S, Furlan R, Bernardi G, Martino G (2010) The link between inflammation, synaptic transmission and neurodegeneration in multiple sclerosis. Cell Death Differ 17 (7):1083-1091. doi:10.1038/cdd.2009.179

37. Hyman MC, Petrovic-Djergovic D, Mazer SP, Pinsky DJ (2007) ENTPDase (CD39) downregulates monocyte and neutrophil MAC-1 expression. Circulation 116:208

38. Hyman MC, Petrovic-Djergovic D, Visovatti SH, Liao H, Yanamadala S, Bouis D, Su EJ, Lawrence DA, Broekman MJ,
Marcus AJ, Pinsky DJ (2009) Self-regulation of inflammatory cell trafficking in mice by the leukocyte surface apyrase CD39. J Clin Invest 119(5):1136-1149. doi:10.1172/JCI36433

39. Bianco F, Ceruti S, Colombo A, Fumagalli M, Ferrari D, Pizzirani C, Matteoli M, Di Virgilio F, Abbracchio MP, Verderio C (2006) A role for P2X7 in microglial proliferation. J Neurochem 99(3):745-758. doi:10.1111/j.1471-4159.2006.04101.x

40. Monif M, Reid CA, Powell KL, Smart ML, Williams DA (2009) The $\mathrm{P} 2 \mathrm{X} 7$ receptor drives microglial activation and proliferation: a trophic role for P2X7R pore. J Neurosci 29(12):3781-3791. doi:10.1523/JNEUROSCI.5512-08.2009

41. Verderio C, Matteoli M (2001) ATP mediates calcium signaling between astrocytes and microglial cells: modulation by IFNgamma. J Immunol 166(10):6383-6391

42. Sharp AJ, Polak PE, Simonini V, Lin SX, Richardson JC, Bongarzone ER, Feinstein DL (2008) P2X7 deficiency suppresses development of experimental autoimmune encephalomyelitis. J Neuroinflammation 5:33. doi:10.1186/17422094-5-33

43. Chen L, Brosnan CF (2006) Exacerbation of experimental autoimmune encephalomyelitis in $\mathrm{P} 2 \mathrm{X} 7 \mathrm{R}-/-$ mice: evidence for loss of apoptotic activity in lymphocytes. J Immunol 176 (5):3115-3126

44. Brough D, Le Feuvre RA, Iwakura Y, Rothwell NJ (2002) Purinergic (P2X7) receptor activation of microglia induces cell death via an interleukin-1-independent mechanism. Mol Cell Neurosci 19(2):272-280. doi:10.1006/mene.2001.1054

45. Alcaraz L, Baxter A, Bent J, Bowers K, Braddock M, Cladingboel D, Donald D, Fagura M, Furber M, Laurent C, Lawson M, Mortimore M, McCormick M, Roberts N, Robertson M (2003) Novel P2X7 receptor antagonists. Bioorg Med Chem Lett 13(22):4043-4046

46. Baxter A, Bennion C, Bent J, Boden K, Brough S, Cooper A, Kinchin E, Kindon N, McInally T, Mortimore M, Roberts B, Unitt J (2003) Hit-to-lead studies: the discovery of potent, orally bioavailable triazolethiol CXCR2 receptor antagonists. Bioorg Med Chem Lett 13(16):2625-2628

47. Friedle SA, Curet MA, Watters JJ (2010) Recent patents on novel P2X7 receptor antagonists and their potential for reducing central nervous system inflammation. Recent Pat CNS Drug Discov 5 (1):35-45

48. Conigrave AD, Fernando KC, Gu B, Tasevski V, Zhang W, Luttrell BM, Wiley JS (2001) $\mathrm{P}^{2} \mathrm{Y}_{11}$ receptor expression by human lymphocytes: evidence for two cAMP-linked purinoceptors. Eur J Pharmacol 426(3):157-163

49. Schnurr M, Toy T, Shin A, Wagner M, Cebon J, Maraskovsky E (2005) Extracellular nucleotide signaling by P2 receptors inhibits IL-12 and enhances IL-23 expression in human dendritic cells: a novel role for the cAMP pathway. Blood 105(4):1582-1589. doi:10.1182/blood-2004-05-1718

50. Ecke D, Fischer B, Reiser G (2008) Diastereoselectivity of the $\mathrm{P}_{2} \mathrm{Y}_{11}$ nucleotide receptor: mutational analysis. Br J Pharmacol 155(8):1250-1255. doi:10.1038/bjp.2008.352

51. Moreschi I, Bruzzone S, Nicholas RA, Fruscione F, Sturla L, Benvenuto F, Usai C, Meis S, Kassack MU, Zocchi E, De Flora A (2006) Extracellular NAD+ is an agonist of the human P2Y $Y_{11}$ purinergic receptor in human granulocytes. J Biol Chem 281 (42):31419-31429. doi:10.1074/jbc.M606625200

52. Vaughan KR, Stokes L, Prince LR, Marriott HM, Meis S, Kassack MU, Bingle CD, Sabroe I, Surprenant A, Whyte MK (2007) Inhibition of neutrophil apoptosis by ATP is mediated by the $\mathrm{P}_{2} \mathrm{Y}_{11}$ receptor. J Immunol 179(12):8544-8553

53. Peterson TS, Camden JM, Wang Y, Seye CI, Wood WG, Sun GY, Erb L, Petris MJ, Weisman GA (2010) P2 $\mathrm{Y}_{2}$ nucleotide receptormediated responses in brain cells. Mol Neurobiol 41(2-3):356 366. doi:10.1007/s12035-010-8115-7 
54. Kong Q, Peterson TS, Baker O, Stanley E, Camden J, Seye CI, Erb L, Simonyi A, Wood WG, Sun GY, Weisman GA (2009) Interleukin-1beta enhances nucleotide-induced and alpha-secretase-dependent amyloid precursor protein processing in rat primary cortical neurons via up-regulation of the $\mathrm{P}_{2} \mathrm{Y}_{2}$ receptor. J Neurochem 109(5):1300-1310. doi:10.1111/ j.1471-4159.2009.06048.x

55. Seye CI, Yu N, Jain R, Kong Q, Minor T, Newton J, Erb L, Gonzalez FA, Weisman GA (2003) The $\mathrm{P}_{2} \mathrm{Y}_{2}$ nucleotide receptor mediates UTP-induced vascular cell adhesion molecule-1 expression in coronary artery endothelial cells. J Biol Chem 278 (27):24960-24965. doi:10.1074/jbc.M301439200

56. Chen Y, Corriden R, Inoue Y, Yip L, Hashiguchi N, Zinkernagel A, Nizet V, Insel PA, Junger WG (2006) ATP release guides neutrophil chemotaxis via $\mathrm{P}_{2} \mathrm{Y}_{2}$ and $\mathrm{A}_{3}$ receptors. Science 314 (5806):1792-1795. doi:10.1126/science.1132559

57. Junger WG (2008) Purinergic regulation of neutrophil chemotaxis. Cell Mol Life Sci 65(16):2528-2540. doi:10.1007/s00018008-8095-1

58. Kukulski F, Ben Yebdri F, Bahrami F, Fausther M, Tremblay A, Sévigny J (2010) Endothelial $\mathrm{P}_{2} \mathrm{Y}_{2}$ receptor regulates LPSinduced neutrophil transendothelial migration in vitro. Mol Immunol 47(5):991-999. doi:10.1016/j.molimm.2009.11.020

59. Stokes L, Surprenant A (2007) Purinergic P2 $Y_{2}$ receptors induce increased MCP-1/CCL2 synthesis and release from rat alveolar and peritoneal macrophages. J Immunol 179(9):6016-6023

60. Ben Yebdri F, Kukulski F, Tremblay A, Sévigny J (2009) Concomitant activation of $\mathrm{P} 2 \mathrm{Y}_{2}$ and $\mathrm{P}_{2} \mathrm{Y}_{6}$ receptors on monocytes is required for TLR1/2-induced neutrophil migration by regulating IL-8 secretion. Eur J Immunol 39(10):2885-2894

61. Fields RD (2011) Nonsynaptic and nonvesicular ATP release from neurons and relevance to neuron-glia signaling. Semin Cell Dev Biol 22(2):214-219. doi:10.1016/j.semcdb.2011.02.009

62. Amadio S, Tramini G, Martorana A, Viscomi MT, Sancesario G, Bernardi G, Volonte C (2006) Oligodendrocytes express P2 $Y_{12}$ metabotropic receptor in adult rat brain. Neuroscience 141 (3):1171-1180. doi:10.1016/j.neuroscience.2006.05.058

63. Irino Y, Nakamura Y, Inoue K, Kohsaka S, Ohsawa K (2008) Akt activation is involved in $\mathrm{P}_{2} \mathrm{Y}_{12}$ receptor-mediated chemotaxis of microglia. J Neurosci Res 86(7):1511-1519. doi:10.1002/jnr.21610

64. Amadio S, Montilli C, Magliozzi R, Bernardi G, Reynolds R, Volonte C (2010) $\mathrm{P}_{2} \mathrm{Y}_{12}$ receptor protein in cortical gray matter lesions in multiple sclerosis. Cereb Cortex 20(6):1263-1273. doi:10.1093/cercor/bhp193

65. Neumann H, Kotter MR, Franklin RJ (2009) Debris clearance by microglia: an essential link between degeneration and regeneration. Brain 132(Pt 2):288-295. doi:10.1093/brain/awn109

66. Kukulski F, Ben Yebdri F, Lefebvre J, Warny M, Tessier PA, Sévigny J (2007) Extracellular nucleotides mediate LPS-induced neutrophil migration in vitro and in vivo. J Leukoc Biol 81 (5): $1269-1275$

67. Koizumi S, Shigemoto-Mogami Y, Nasu-Tada K, Shinozaki Y, Ohsawa K, Tsuda M, Joshi BV, Jacobson KA, Kohsaka S, Inoue K (2007) UDP acting at $\mathrm{P}_{2} \mathrm{Y}_{6}$ receptors is a mediator of microglial phagocytosis. Nature 446(7139):1091-1095. doi:10.1038/ nature 05704

68. Ceruti S, Villa G, Genovese T, Mazzon E, Longhi R, Rosa P, Bramanti P, Cuzzocrea S, Abbracchio MP (2009) The P2Y-like receptor GPR17 as a sensor of damage and a new potential target in spinal cord injury. Brain 132(Pt 8):2206-2218. doi:10.1093/ brain/awp 147

69. Ceruti S, Vigano F, Boda E, Ferrario S, Magni G, Boccazzi M, Rosa P, Buffo A, Abbracchio MP (2011) Expression of the new P2Y-like receptor GPR17 during oligodendrocyte precursor cell maturation regulates sensitivity to ATP-induced death. Glia 59 (3):363-378. doi:10.1002/glia.21107
70. Lecca D, Trincavelli ML, Gelosa P, Sironi L, Ciana P, Fumagalli M, Villa G, Verderio C, Grumelli C, Guerrini U, Tremoli E, Rosa P, Cuboni S, Martini C, Buffo A, Cimino M, Abbracchio MP (2008) The recently identified P2Y-like receptor GPR17 is a sensor of brain damage and a new target for brain repair. PLoS One 3(10):e3579. doi:10.1371/journal.pone.0003579

71. Chen Y, Wu H, Wang S, Koito H, Li J, Ye F, Hoang J, Escobar SS, Gow A, Arnett HA, Trapp BD, Karandikar NJ, Hsieh J, Lu QR (2009) The oligodendrocyte-specific G protein-coupled receptor GPR17 is a cell-intrinsic timer of myelination. Nat Neurosci 12(11):1398-1406. doi:10.1038/nn.2410

72. Fumagalli M, Daniele S, Lecca D, Lee PR, Parravicini C, Fields RD, Rosa P, Antonucci F, Verderio C, Trincavelli ML, Bramanti P, Martini C, Abbracchio MP (2011) Phenotypic changes, signaling pathway, and functional correlates of GPR17-expressing neural precursor cells during oligodendrocyte differentiation. J Biol Chem 286(12):10593-10604. doi:10.1074/jbc.M110.162867

73. Stone TW, Ceruti S, Abbracchio MP (2009) Adenosine receptors and neurological disease: neuroprotection and neurodegeneration. Handb Exp Pharmacol 193:535-587. doi:10.1007/978-3540-89615-9_17

74. Linden $\mathrm{J}$ (2005) Adenosine in tissue protection and tissue regeneration. Mol Pharmacol 67(5):1385-1387. doi:10.1124/ mol.105.011783

75. Abbracchio MP, Ceruti S (2007) P1 receptors and cytokine secretion. Purinergic Signal 3(1-2):13-25. doi:10.1007/s11302006-9033-z

76. Sitkovsky MV, Lukashev D, Apasov S, Kojima H, Koshiba M, Caldwell C, Ohta A, Thiel M (2004) Physiological control of immune response and inflammatory tissue damage by hypoxiainducible factors and adenosine $\mathrm{A}_{2 \mathrm{~A}}$ receptors. Annu Rev Immunol 22:657-682. doi:10.1146/annurev.immunol.22.012703.104731

77. Sitkovsky MV, Ohta A (2005) The 'danger' sensors that STOP the immune response: the $\mathrm{A}_{2}$ adenosine receptors? Trends Immunol 26(6):299-304. doi:10.1016/j.it.2005.04.004

78. Synnestvedt K, Furuta GT, Comerford KM, Louis N, Karhausen J, Eltzschig HK, Hansen KR, Thompson LF, Colgan SP (2002) Ecto-5'-nucleotidase (CD73) regulation by hypoxia-inducible factor-1 mediates permeability changes in intestinal epithelia. $\mathrm{J}$ Clin Invest 110(7):993-1002

79. Eltzschig HK, Kohler D, Eckle T, Kong T, Robson SC, Colgan SP (2009) Central role of Sp1-regulated CD39 in hypoxia/ ischemia protection. Blood 113(1):224-232. doi:10.1182/blood2008-06-165746

80. Hasko G, Pacher P, Vizi ES, Illes P (2005) Adenosine receptor signaling in the brain immune system. Trends Pharmacol Sci 26 (10):511-516. doi:10.1016/j.tips.2005.08.004

81. Tsutsui S, Schnermann J, Noorbakhsh F, Henry S, Yong VW, Winston BW, Warren K, Power C (2004) $\mathrm{A}_{1}$ adenosine receptor upregulation and activation attenuates neuroinflammation and demyelination in a model of multiple sclerosis. J Neurosci 24 (6):1521-1529. doi:10.1523/JNEUROSCI.4271-03.2004

82. Mayne M, Shepel PN, Jiang Y, Geiger JD, Power C (1999) Dysregulation of adenosine $\mathrm{A}_{1}$ receptor-mediated cytokine expression in peripheral blood mononuclear cells from multiple sclerosis patients. Ann Neurol 45(5):633-639

83. Johnston JB, Silva C, Gonzalez G, Holden J, Warren KG, Metz LM, Power C (2001) Diminished adenosine $A_{1}$ receptor expression on macrophages in brain and blood of patients with multiple sclerosis. Ann Neurol 49(5):650-658

84. Deuchars SA, Brooke RE, Deuchars J (2001) Adenosine $A_{1}$ receptors reduce release from excitatory but not inhibitory synaptic inputs onto lateral horn neurons. J Neurosci 21 (16):6308-6320

85. Ciccarelli R, Di Iorio P, Bruno V, Battaglia G, D'Alimonte I, D'Onofrio M, Nicoletti F, Caciagli F (1999) Activation of $A_{1}$ 
adenosine or mGlu3 metabotropic glutamate receptors enhances the release of nerve growth factor and S-100beta protein from cultured astrocytes. Glia 27(3):275-281. doi:10.1002/(SICI) 1098-1136(199909)27:3<275::AID-GLIA9>3.0.CO;2-0

86. Gessi S, Varani K, Merighi S, Fogli E, Sacchetto V, Benini A, Leung E, Mac-Lennan S, Borea PA (2007) Adenosine and lymphocyte regulation. Purinergic Signal 3(1-2):109-116. doi:10.1007/s11302-006-9042-y

87. Trincavelli ML, Marroni M, Tuscano D, Ceruti S, Mazzola A, Mitro N, Abbracchio MP, Martini C (2004) Regulation of $A_{2 B}$ adenosine receptor functioning by tumour necrosis factor a in human astroglial cells. J Neurochem 91(5):1180-1190. doi:10.1111/j.1471-4159.2004.02793.x

88. Schwaninger M, Neher M, Viegas E, Schneider A, Spranger M (1997) Stimulation of interleukin-6 secretion and gene transcription in primary astrocytes by adenosine. J Neurochem 69(3):1145-1150

89. Wittendorp MC, Boddeke HW, Biber K (2004) Adenosine $A_{3}$ receptor-induced CCL2 synthesis in cultured mouse astrocytes. Glia 46(4):410-418. doi:10.1002/glia.20016

90. Lee JY, Jhun BS, Oh YT, Lee JH, Choe W, Baik HH, Ha J, Yoon KS, Kim SS, Kang I (2006) Activation of adenosine $\mathrm{A}_{3}$ receptor suppresses lipopolysaccharide-induced TNF-alpha production through inhibition of PI 3-kinase/Akt and NF-kappaB activation in murine BV2 microglial cells. Neurosci Lett 396(1):1-6. doi:10.1016/j.neulet.2005.11.004

91. Kukulski F, Komoszynski M (2003) Purification and characterization of NTPDase1 (ecto-apyrase) and NTPDase2 (ectoATPase) from porcine brain cortex synaptosomes. Eur J Biochem 270(16):3447-3454

92. Borsellino G, Kleinewietfeld M, Di Mitri D, Sternjak A, Diamantini A, Giometto R, Hopner S, Centonze D, Bernardi G, Dell'Acqua ML, Rossini PM, Battistini L, Rotzschke O, Falk K (2007) Expression of ectonucleotidase CD39 by Foxp3+ Treg cells: hydrolysis of extracellular ATP and immune suppression. Blood 110(4):1225-1232. doi:10.1182/blood-2006-12-064527

93. Pulte ED, Broekman MJ, Olson KE, Drosopoulos JH, Kizer JR, Islam N, Marcus AJ (2007) CD39/NTPDase-1 activity and expression in normal leukocytes. Thromb Res 121(3):309-317. doi:10.1016/j.thromres.2007.04.008

94. Dwyer KM, Deaglio S, Gao W, Friedman D, Strom TB, Robson SC (2007) CD39 and control of cellular immune responses. Purinergic Signal 3(1-2):171-180. doi:10.1007/s11302-006-9050-y

95. Fletcher JM, Lonergan R, Costelloe L, Kinsella K, Moran B, O'Farrelly C, Tubridy N, Mills KH (2009) CD39+Foxp3+ regulatory $\mathrm{T}$ Cells suppress pathogenic Th17 cells and are impaired in multiple sclerosis. J Immunol 183(11):7602-7610. doi:10.4049/jimmunol.0901881
96. Kukulski F, Bahrami F, Ben Yebdri F, Lecka J, Martín-Satué M, Lévesque SA, Sévigny J (2011) NTPDase 1 controls IL-8 production by human neutrophils. J Immunol 187(2):644-653

97. Lévesque SA, Kukulski F, Enjyoji K, Robson SC, Sévigny J (2010) NTPDase1 governs P2X7-dependent functions in murine macrophages. Eur J Immunol 40(5):1473-1485. doi:10.1002/ eji.200939741

98. Imai M, Goepfert C, Kaczmarek E, Robson SC (2000) CD39 modulates IL-1 release from activated endothelial cells. Biochem Biophys Res Commun 270(1):272-278. doi:10.1006/ bbrc. 2000.2410

99. Liao H, Hyman MC, Baek AE, Fukase K, Pinsky DJ (2010) cAMP/ CREB-mediated transcriptional regulation of ectonucleoside triphosphate diphosphohydrolase 1 (CD39) expression. J Biol Chem 285(19):14791-14805. doi:10.1074/jbc.M110.116905

100. Spanevello RM, Mazzanti CM, Bagatini M, Correa M, Schmatz R, Stefanello N, Thome G, Morsch VM, Becker L, Belle L, de Oliveira L, Schetinger MR (2010) Activities of the enzymes that hydrolyze adenine nucleotides in platelets from multiple sclerosis patients. J Neurol 257(1):24-30. doi:10.1007/s00415-009-5258-4

101. Spanevello RM, Mazzanti CM, Schmatz R, Thome G, Bagatini M, Correa M, Rosa C, Stefanello N, Belle LP, Moretto MB, Oliveira L, Morsch VM, Schetinger MR (2010) The activity and expression of NTPDase is altered in lymphocytes of multiple sclerosis patients. Clin Chim Acta 411(3-4):210-214. doi:10.1016/j.cca.2009.11.005

102. Airas L, Niemela J, Yegutkin G, Jalkanen S (2007) Mechanism of action of IFN-beta in the treatment of multiple sclerosis: a special reference to CD73 and adenosine. Ann N Y Acad Sci 1110:641-648. doi:10.1196/annals. 1423.067

103. Niemela J, Ifergan I, Yegutkin GG, Jalkanen S, Prat A, Airas L (2008) IFN-beta regulates CD73 and adenosine expression at the blood-brain barrier. Eur J Immunol 38(10):2718-2726. doi:10.1002/eji.200838437

104. Franco R, Casado V, Ciruela F, Saura C, Mallol J, Canela EI, Lluis C (1997) Cell surface adenosine deaminase: much more than an ectoenzyme. Prog Neurobiol 52(4):283-294

105. Vivekanandhan S, Soundararajan CC, Tripathi M, Maheshwari MC (2005) Adenosine deaminase and 5'-nucleotidase activities in peripheral blood $\mathrm{T}$ cells of multiple sclerosis patients. Neurochem Res 30(4):453-456

106. Czarnecka J, Cieslak M, Komoszynski M (2005) Application of solid phase extraction and high-performance liquid chromatography to qualitative and quantitative analysis of nucleotides and nucleosides in human cerebrospinal fluid. J Chromatogr B Analyt Technol Biomed Life Sci 822(1-2):85-90. doi:10.1016/ j.jchromb.2005.05.026 